\title{
Bitcoin -
}

\section{zagadnienia prawno-podatkowe}

\author{
Bitcoin - legal and tax issues
}

\section{Kryptowaluty w regulacjach prawnych wybranych krajów}

Bitcoin można określić jako zdecentralizowany cyfrowy pieniądz, który jest przesyłany od użytkownika do użytkownika w sieci bitcoin, ale jego wartość nie jest wspierana przez żaden bank centralny. Taką formę pieniądza określa się również jako kryptowalutę. Słownik oksfordzki definiuje bitcoina jako „rodzaj cyfrowej waluty, w której używa się technik szyfrowania do regulacji generowania jednostek waluty i sprawdzania przepływów funduszy, działających niezależnie od banku centralnego; bitcoin stał się towarem spekulacyjnym" (Oxford Dictionary, 2010). Z kolei Europejski Bank Centralny już w 2012 r. zdefiniował wirtualne waluty jako „niepodlegający regulacjom prawnym typ pieniądza wydawany w środowisku elektronicznym [...]" (EBC, 2012), a w 2015 r. uznał ją za „cyfrową reprezentację wartości niewyemitowanej przez bank cenralny [...], która w pewnych okoliczościach może być użyta jako alternatywa dla pieniądza” (EBC, 2015). Definicje te wskazują, iż cyfrowa waluta, kryptowaluta czy wirtualna waluta to nazwy stosowane zamiennie. W piśmiennictwie można spotkać dalsze synonimy tego pojęcia: cyber-pieniądz, cyfrowy pieniądz. Od momentu pojawienia się bitcoina w 2009 r powstało wiele prac, które wyjaśniają różnice semantyczne, ale nie ma sporu co do tego, że jest to nowa forma zdigitalizowanego pieniądza, który budzi zainteresowanie na całym świecie. Użyte w artykule określenia sprowadzają się do synonimów tego samego zjawiska. 
W ostatnim dziecięcioleciu powstało wiele sieciowych systemów płatności, z których bitcoin jest wciąż najbardziej popularną wirtualną walutą, głównie ze względu na swoje pozasystemowe rozwiązania ${ }^{1}$. To z kolei wymusza podejmowanie przez rządzących określonych działań w poszczególnych krajach świata, które wynikają z dwóch powodów:

1) bitcoin jest „dobrem rzadkim i pożądanym” - niejako substytutem pieniądza narodowego ${ }^{2}$;

2) bitcoin nie jest powszechnie regulowanym środkiem płatniczym kontrolowanym przez rządy, przez co może być wykorzystywany do celów niezgodnych z prawem (Brito, Castilo, 2016).

Pierwszy powód wskazuje na to, że ludzie zawsze byli skłonni do posiadania twardego pieniądza, a w tym przypadku do wymiany posiadanych przez siebie narodowych środków pieniężnych na bitcoiny. Istnienie konkurencyjnych walut nie jest niczym nowym, ponieważ lokalne, nieuregulowane społeczności walutowe istniały na długo przed erą cyfrową. Oczywiste jest jednak, że z jednej strony użytkowanie współczesnych systemów, takich jak bitcoin, bez odpowiednich regulacji może stanowić zagrożenie dla ich użytkowników, a z drugiej - stwarza wyzwania dla globalnego systemu bankowego, który jest ściśle uregulowany i kontrolowany.

Drugi powód wydaje się jeszcze ważniejszy. Kwestia wykorzystywania wirtualnych walut w obrocie handlowym rodzi ryzyko nadużyć finansowych w wyniku dokonywania nielegalnych transakcji. Przykładowo, w styczniu 2014 r. amerykańskie służby rządowe aresztowały Charliego Shrema (Ledger, 2014), oskarżając go o pranie pieniędzy na nieistniejącej już platformie internetowej Silk Road (Hurtado, 2014). Organy ścigania próbowały w ten sposób zapobiec używaniu bitcoina na witrynach internetowych, na których można zakupić narkotyki, broń, uzyskać dostęp do pornografii czy innych nielegalnych towarów i usług.

Podejmowane próby rozszerzenia prawnej uznawalności bitcoina i jego legalizacji należy postrzegać w wymiarze pozytywnym. Współczesne, alternatywne systemy mogą mieć korzystne aspekty, zwłaszcza gdy przyczyniają się do rozwoju innowacji finansowych i zapewniają użytkownikom dodatkowe alternatywy płatności. Rządy powinny regulować kwestie wirtualnych walut dla ich własnego dobra (Lam, Lee, 2015), gdyż postępowanie wbrew rozwijającym

\footnotetext{
1 Bitcoin funkcjonuje w systemie peer-to-peer, w którym klucz publiczny służy do potwierdzania dokonywanych transakcji bitcoinowych, a skutkiem ubocznym tych operacji są wygenerowane nowe jednostki bitcoinowe.

2 El Salwador jako pierwszy kraj na świecie wprowadził - od 7 września 2021 r. - bitcoina jako legalną walutą (reuters.com).
} 
się trendom jest działaniem nadmiernie kosztownym, skazanym na porażkę i prowadzącym do niepożądanych procesów (hamowanie rozwoju technologii, przekierowanie użytkowników do niewidzialnych sieci, zawieranie nielegalnych transakcji, wprowadzanie do obiegu „wypranych” środków).

Dobrym przykładem może być rząd angielski, który w sierpniu 2014 r. podjął prace w celu zbadania korzyści i zagrożeń związanych z technologią walut cyfrowych oraz uwzględnieniem kwestii dotyczących regulacji tego rynku. Przeprowadzono konsultacje społeczne, włączając w nie użytkowników walut cyfrowych, ich twórców, firmy świadczące usługi związane z walutami cyfrowymi, banki, firmy zajmujące się systemami płatności, naukowców, firmy konsultingowe oraz inne departamenty i agencje rządowe (HM Treasury, 2015). W efekcie przeprowadzonych konsultacji społecznych rząd brytyjski zabezpieczył w budżecie pakiet środków mających na celu rozwiązanie kluczowych zagrożeń związanych z przestępczością i ochroną konsumentów cyfrowych walut. W ten sposób stworzono odpowiednie środowisko dla działalności legalnych podmiotów oraz dla nielegalnych użytkowników walut cyfrowych ${ }^{3}$.

Amerykańskie przepisy skarbowe i działania podejmowane na szczeblu państwa pokazują, że bitcoin może być wykorzystywany do legalnych zakupów, ale musi podlegać stanowym regulacjom dotyczącym prania pieniędzy. W kwestii rozpoznania najlepszych rozwiązań w sprawie legalnego obrotu bitcoinem, najdalej idące działania poczyniła Biblioteka Prawa Kongresu Stanów Zjednoczonych, podejmując się zbadania regulacji prawnych 40 różnych krajów (Ramasastry, 2014) w celu zidentyfikowania, które państwa i w jakim zakresie wprowadziły uregulowania dla wirtualnych walut, w tym bitcoina. W wyniku przeprowadzonego badania zauważono znaczące różnice w podejściu do tego zagadnienia, co umożliwiło podzielenie poszczególnych krajów na cztery grupy (Tu, Meredith, 2015): 1) państwa, w których brak było jakichkolwiek działań mających na celu wdrożenie regulacji dla wirtualnych walut; 2) kraje, które zajęły się kwestią opodatkowania wirtualnych walut, ale nie podjęły działań z zakresu dalszych regulacji tego rynku; 3) państwa zakazujące lub ograniczające handel wirtualną walutą; 4) kraje wstępnie uznające wirtualne waluty za formę pieniądza.

${ }^{3}$ Od 2015 r. Bank Anglii prowadził nowe badania i prace nad walutami cyfrowymi emitowanymi przez angielski bank centralny. Pojawienie się nowych i przełomowych technologii w przestrzeni walutowej stwarza ogromną presję na te instytucje na całym świecie, aby konkurować i uzupełnić niektóre aspekty nowych technologii w celu modernizacji tradycyjnych walut. Banki centralne są świadome zagrożeń w obliczu rozwoju cyfrowych walut, dlatego chcą wykorzystać technologię do konstrukcji własnych walut fiducjarnych, aby stać się konkurencyjnymi wobec walut, takich jak bitcoin. W efekcie tych prac powstał cyfrowy funt szterling. 
Tabela 1. Kraje według podejścia do wirtualnych walut ${ }^{4}$

\begin{tabular}{|c|c|c|}
\hline \multicolumn{2}{|c|}{$\begin{array}{l}\text { Kraje, w których brak działań mają- } \\
\text { cych na celu wdrożenie regulacji dla } \\
\text { wirtualnych walut }\end{array}$} & $\begin{array}{l}\text { Kraje wyjaśniające kwestie opodatkowania } \\
\text { wirtualnych walut, lecz nieregulujące dalszych } \\
\text { kwestii w tym zakresie }\end{array}$ \\
\hline $\begin{array}{l}\text { Alderney } \\
\text { Argentyna } \\
\text { Australia } \\
\text { Belgia } \\
\text { Kanada } \\
\text { Chile } \\
\text { Chorwacja } \\
\text { Cypr } \\
\text { Dania } \\
\text { Estonia } \\
\text { Francja } \\
\text { Grecja } \\
\text { Hongkong } \\
\text { Indie } \\
\text { Indonezja } \\
\text { Irlandia }\end{array}$ & $\begin{array}{l}\text { Japonia } \\
\text { Korea Południowa } \\
\text { Malezja } \\
\text { Malta } \\
\text { Holandia } \\
\text { Nowa Zelandia } \\
\text { Nikaragua } \\
\text { Polska } \\
\text { Portugalia } \\
\text { Rosja } \\
\text { Singapur } \\
\text { Taiwan } \\
\text { Turcja } \\
\text { Włochy }\end{array}$ & $\begin{array}{l}\text { Finlandia } \\
\text { Hiszpania } \\
\text { Izrael } \\
\text { Norwegia } \\
\text { Słowenia } \\
\text { Wielka Brytania }\end{array}$ \\
\hline $\begin{array}{l}\text { Kraje zak } \\
\text { korzystan }\end{array}$ & $\begin{array}{l}\text { jące lub ograniczające } \\
\text { z wirtualnych walut }\end{array}$ & $\begin{array}{l}\text { Kraje uznające wirtualną walutę za formę } \\
\text { pieniądza }\end{array}$ \\
\hline $\begin{array}{l}\text { Chiny } \\
\text { Islandia } \\
\text { Tajlandia }\end{array}$ & & $\begin{array}{l}\text { Brazylia } \\
\text { Niemcy } \\
\text { Szwecja }\end{array}$ \\
\hline
\end{tabular}

Źródło: opracowanie własne na podstawie Tu, Meredith, 2015.

Na uwagę zasługuje fakt, iż powstanie alternatywnego systemu pieniądza początkowo wywołało reakcje obserwacyjne, stąd w pierwszej grupie znalazło się większość badanych krajów. Są to państwa, które nie zajęły się formalnymi regulacjami w celu określenia zasad dotyczących obrotu i funkcjonowania cyfrowych walut. Być może, zdając sobie sprawę z niezmierzonych możliwości sieci internetowej, kraje te nie zdecydowały się na podejmowanie przedwczesnych i zdecydowanych decyzji zakazujących używania wirtualnej waluty. Brak odpowiednich regulacji prawnych spowodowany jest tym, że regulatorzy nie nadążają za pojawiającymi się na rynku technologicznymi wynalazkami. Decydenci rządowi potrzebują poświęcenia większej ilości czasu dla lepszego rozpoznania ryzyk i podjęcia decyzji, w jaki sposób i kiedy funkcjonowanie wirtualnych walut zostanie prawnie uregulowane.

4 Nieco nowszy podział podejścia do wirtualnych walut można znaleźć w artykule Kryptowaluty - pojęcie, cechy, kontrowersje (Marszałek, 2019). 
Do następnego gremium zakwalifikowały się kraje skoncentrowane na kwestii opodatkowania cyfrowych walut. Wielka Brytania oświadczyła, że „Bitcoin jest obecnie nieuregulowany”, a mimo to brytyjski urząd skarbowy zaliczył go do „bonów pojedynczego celu”, czyli dóbr opodatkowanych stawką podatku od wartości dodanej na poziomie 10-20\%. Plany uregulowania cyfrowych walut przedstawiono w raporcie Digital currencies: response to the call for information (2015), w którym podkreślono nowatorski wkład wirtualnych walut w rozwój dziedziny technologii płatniczych z wykorzystaniem rozproszonych sieci peer-to-peer oraz technik kryptograficznych, umożliwiających efektywny i bezpieczny transfer cyfrowych środków pomiędzy użytkownikami. Uwagę zwraca fakt, że potencjalne korzyści, jakie oferują rozwiązania zastosowane w wirtualnych systemach walut, mogą być efektywnie wykorzystane w mikropłatnościach i transakcjach transgranicznych. Norwegia, Hiszpania i Finlandia zaaprobowały bitcoina jako przedmiot majątku kapitałowego, którego stawka opodatkowania podatkiem od wartości dodanej wynosi do 25\%. Inną postawę przyjęły Słowenia i Izrael, interpretując zyski pochodzące z obrotu wirtualną walutą jako przychód przeznaczony do opodatkowania.

Jak widać, traktowanie zagadnień podatkowych w granicach poszczególnych krajów jest nieco inne (Arnfield, 2015). Koncentrację jedynie na obostrzeniach podatkowych i brak regulacji w pozostałych obszarach prawnych (związanych z niepewnością sposobów użytkowania wirtualnych walut) można uznać za niepowodzenie rządzących (Przyłuska-Schmitt, 2016).

W trzeciej grupie znalazły się te państwa, które zdecydowały o wprowadzeniu zakazu lub znacznych ograniczeń wobec użytkowników bitcoina. Bank Tajlandii oświadczył, że ta kryptowaluta jest nielegalna. Również Urząd Rosyjskiego Prokuratora Generalnego stwierdził, że bitcoiny i inne waluty kryptograficzne nie mogą być legalnie stosowane w Rosji. Na poparcie swojego stanowiska rosyjskie organy ścigania cytowały ustawę dewizową z 2002 r., z której wynika, że oficjalną walutą Federacji Rosyjskiej jest rubel. Wprowadzenie innych jednostek monetarnych i substytutów pieniądza jest zabronione. Rosyjski Bank Centralny uważa, że legalizacja kryptowalut zagraża stabilności finansowej, systemowi przeciwdziałania praniu pieniędzy oraz sektorowi ochrony konsumentów. Bank Centralny nie wprowadził zakazu posiadania cyfrowej waluty, ale zakazał jej emitowania i wpuszczania do obiegu (Palczewski, 2020).

W miarę wzrostu rynku wirtualnych walut zdecydowane działania podjął także Ludowy Bank Chin, który już w grudniu 2013 r. zakazał instytucjom finansowym oraz instytucjom usług płatniczych rozliczeń biznesowych przy użyciu bitcoina. Decyzję taką podjęto w celu uniknięcia oszustw finanowych oraz kieru- 
jąc się statusem prawnym renminbi [juana], które mogłyby ucierpieć w wyniku nadmiernej spekulacji bitcoinem i innymi dobrami wirtualnymi (Ramasastry 2014). Mimo to w Chinach nie zdecydowano się na całkowite wyeliminowanie cyfrowego pieniądza z obrotu i nie uznano go za nielegalny (Hill, 2013). Wraz $\mathrm{z}$ upływem lat Chiny zmieniły podejście do kryptowalut i w dniu 18 lipca $2019 \mathrm{r}$. bitcoin zyskał uznanie prawne chińskiego sądu, co umacnia jego status w jednej z najtrudniejszych jurysdykcji na świecie. W tej samej grupie znalazła się Islandia, która na podstawie krajowej ustawy dewizowej zakazała angażowania się w obrót krytowalutami.

Problematyka bitcoina okazała się najbardziej zrozumiała dla czwartej grupy państw zakwalifikowanych do tych, które uznają ważność walut wirtualnych i starają się implemenować przepisy w zakresie umożliwienia powszechnego ich użytkowania. W tym celu wykorzystują koncepcje tradycyjnych regulacji finansowych, przystosowując je do alternatywnej formy pieniądza. Dominujące kraje tej grupy to: Brazylia, Niemcy i Szwecja.

Dnia 9 października 2013 r. Brazylia uchwaliła ustawę dopuszczającą znormalizowanie systemów płatności mobilnych i tworzenie elektronicznych środków płatności w postaci walut, takich jak bitcoin.

W Niemczech organ nadzoru nad rynkiem finansowym BaFin już w 2011 r. zdefiniował cyfrowe środki płatnicze jako waluty uzupełniające, emitowane na podstawie prawa prywatnego i zaklasyfikował je jako jednostki rozliczeniowe (BaFin, 2011; Schmid, 2019). Zaakceptowano wymianę bitcoina w ramach świadczenia usług finansowych po spełnieniu przez firmy (zainteresowane obrotem kryptowalutami) określonych standardów dotyczących wymogów kapitałowych: posiadania odpowiednich kwalifikacji zawodowych oraz raportowania przeprowadzonych transakcji do BaFin (BaFin, 2014) ${ }^{5}$. Niemcy poczyniły następne kroki i obecnie regulują wirtualne waluty jako aktywa cyfrowe. Wraz z ustawą dotyczącą prania pieniędzy wdrożono regulacje dotyczące systemu blockchain. Bundestag uchwalił je w listopadzie 2019 r., ale liczne zmiany weszły w życie dnia 1 stycznia 2020 r. Wynika z nich, że każdy, kto opiera swój model biznesowy na bitcoinach lub innych kryptowalutach, musi posiadać zezwolenie Federalnego Urzędu Nadzoru Finansowego. W regulacjach przyjęto zasady podobne do tych, które dopuszczono w Stanach Zjednoczonych. Dodatkowo niemiecki rząd, wychodząc naprzeciw zainteresowaniom sektora finansowego „blockchainem”,

5 Wiele niemieckich źródeł opartych na wyjaśnieniach BaFin przytacza nieuregulowany stan bitcoina $\mathrm{w}$ wielu kwestiach. Niemcy koncentrują się głównie na kwestiach podatkowych, traktują BTC jako instrument finansowy, a nie jako środek płatniczy ani e-pieniadz. Zob. stanowisko BaFin w artykule Münzer, 2014. 
dnia 18 września 2019 r. przyjął strategię, której celem jest „wytyczenie kursu dla tokenowej ekonomii", uregulowanie obrotu tymi aktywami i ich przechowywania, wpływając w ten sposób znacząco na niemiecki rynek FinTech (Sandner, Blassl, 2020). W tej samej grupie znalazła się także Szwecja, która nie stworzyła dla wirtualnych walut szczególnych ram prawnych, ale postrzega bitcoina jako usługę finansową, podlegającą obowiązkowi składania sprawozdań.

Powyższe przykłady dowodzą, że problematyka kryptowalut jest na tyle istotna, iż wiele krajów próbuje zaprojektować ramy prawne dla legalnego ich użytkowania. Państwa, które zakwalifikowano do czwartej grupy, okazały się bardziej świadome negatywnych konsekwencji (wynikających z zakazu użytkowania wirtualnych walut) dla regulowanego systemu finansowego, stąd umożliwiają dalszy rozwój wirtualnego pieniądza, obserwują jego rozwój i podejmują działania mające na celu zminimalizowanie związanego z nim ryzyka ${ }^{6}$. Są jednak kraje zajmujące stanowisko wrogie wobec rozwoju i użytkowania takich walut. Wydaje się jednak, iż postawa taka narażona jest na porażkę. Możliwości stworzone przez sieć internetową stają się o wiele większe niż zdolność rządów do efektywnego ich ograniczania. Skoro więc zakazy stają się nieskuteczne, to prędzej czy później rządy muszą dopuścić alternatywne systemy płatności i umożliwić legalny obrót wirtualnym pieniądzem. Obecnie przyglądają się, testują i dostosowują system finansowy do potrzeb globalnego społeczeństwa cyfrowego.

\section{Orzeczenie TSUE w sprawie wirtualnych walut}

W Europie widoczny jest postęp podejmowanych w tym zakresie działań, tak jak ma to miejsce w Stanach Zjednoczonych (Middlebrook, Hughes, 2013). W obszarze opodatkowania czynności wymiany bitcoina na walutę tradycyjną i odwrotnie pierwszy istotny przełom nastąpił 22 października 2015 r., kiedy Trybunał Sprawiedliwości Unii Europejskiej (TSUE) wydał w tej sprawie pozytywne orzeczenie dla podatnika. Mowa w nim o trudnościach związanych $\mathrm{z}$ ustaleniem podstawy opodatkowania oraz kwoty podlegającej odliczeniu od podatku VAT. W uzasadnieniu podano, że w przypadku wirtualnych walut zasady odliczeń mogą być takie same jak w obrocie walutami tradycyjnymi zwolnionymi z opodatkowania (na podstawie art. 135 ust. 1 lit. e dyrektywy o VAT). Co istotne,

\footnotetext{
6 Autor ma tu na myśli walkę z szarą strefą, która posługuje się gotówką jako środkiem regulowania nielegalnych zobowiązań poza systemem bankowym.
} 
rozważany problem dotyczył wymiany narodowych walut na waluty wirtualne w tzw. systemie „dwukierunkowego przepływu”7.

Orzeczenie TSUE okazało się przełomowe dla rynku kryptowalut i wynika z niego, że kryptowaluta bitcoin jest używana w sposób odpowiadający prawnym środkom płatniczym. Wymiana dotycząca walut cyfrowych jest uznawana za transakcję finansową, jeśli została zaakceptowana przez strony dokonujące wymiany jako inny środek płatniczy, a ich jedynym przeznaczeniem jest użycie w ramach funkcji płatniczej. A zatem według TSUE świadczenie usługi polegającej na wymianie walut narodowych na jednostki wirtualnej waluty (takiej jak bitcoin) i odwrotnie za opłatą sumy będącej marżą wynikającą z różnicy pomiędzy ceną nabycia waluty a ceną sprzedaży waluty przez przedsiębiorcę jest transakcją zwolnioną z podatku VAT (Kiszka, 2016; Wasilewska, 2015).

Wyrok TSUE okazał się bezprecedensowy wobec interpretacji indywidualnych wydawanych przez izby skarbowe i instytucje podatkowe w krajach członkowskich UE, w tym także w Polsce.

\section{Przegląd interpretacji podatkowych polskich izb skarbo- wych w obszarze wirtualnych walut}

Izba Skarbowa w Warszawie zajęła stanowisko zbieżne z TSUE jeszcze przed wydaniem orzeczenia przez trybunał. W wydanej w dniu 24 czerwca 2014 r. interpretacji indywidualnej wskazała, że używanie alternatywnego środka płatniczego (bitcoin) w celu umarzania zobowiązań nie podlega VAT (IPPP2/443-334/14-2/ $\mathrm{BH}, 2014)$. Tożsame stanowisko podzieliła Izba Skarbowa w Warszawie w wydanej dnia 15 lutego 2016 r. interpretacji indywidualnej. Stwierdziła, że charakter prawny kupowanych jednostek bitcoin przy ich akceptacji przez strony transakcji jako alternatywnego środka płatniczego pozwala uznać wirtualną walutę za nośnik wartości pieniężnej oraz środek płatniczy (IPPP3/4512-1005/15-2/RD, 2016).

Składane wnioski o interpretacje podatkowe w obszarze obrotu bitcoinem nie dotyczą jednak tylko podatku VAT. Wyjaśnienia wymagają liczne zapytania w zakresie: opodatkowania prowizji, kosztów uzyskania przychodu, dokumentowania transakcji, momentu powstania obowiązku podatkowego, wycofania kryptowalut z giełdy, obowiązku założenia i wskazania miejsca działalności gospodarczej czy też dopuszczalnej formy opodatkowania w obrocie wirtualnymi walutami.

\footnotetext{
7 Dwukierunkowy przepływ lub systemy dwukierunkowe to takie, w których wirtualna waluta może być wymieniana na inne waluty bez ograniczeń, a rolę wejścia i wyjścia pełnią najczęściej giełdy, kantory i innego rodzaju pośrednicy.
} 
Izba Skarbowa w Warszawie w dniu 12 lutego 2016 r. na pytanie wnioskodawcy, „czy kwota prowizji naliczanych od zrealizowanych transakcji walutą bitcoin podlega zwolnieniu czy opodatkowaniu podatkiem towarów i usług", uznała, iż czynności przedstawione przez wnioskodawcę są świadczeniem usług podlegającym opodatkowaniu VAT. Dodatkowo przywołano art. 73 Dyrektywy Rady 2006/112/WE z dnia 28 listopada 2006 r. w sprawie wspólnego systemu podatku od wartości dodanej, który za podstawę opodatkowania uznaje wszystko, co obejmuje dokonaną lub otrzymaną w przyszłości zapłatę od nabywcy/ usługobiorcy lub osoby trzeciej.

Do kolejnego rozstrzygnięcia dołączyła kwestia interpretacji „miejsca opodatkowania podatkiem VAT czynności sprzedaży wirtualnej waluty dokonywanej poprzez stronę internetową dla podmiotów niemających siedziby i miejsca prowadzenia działalności gospodarczej, miejsca stałego zamieszkania lub zwykłego pobytu w Polsce". Organ podatkowy w Warszawie uznał, iż miejscem świadczenia przedmiotowej usługi oraz miejscem opodatkowania wirtualnej waluty będzie Polska, jeśli usługi te będą świadczone dla stałego miejsca prowadzenia działalności w tym kraju. Powyższe dotyczy również podmiotów nieprowadzących działalności gospodarczej, ale mających stałe miejsce zamieszkania lub pobytu w Polsce (IPPP3/4512-626/15-2/RD, 2015). A zatem z punktu widzenia podatku dochodowego od osób fizycznych można wyróżnić dwa podejścia:

1) podatnicy dokonujący transakcji cyfrowymi walutami w ramach prowadzonej działalności;

2) osoby fizyczne nieprowadzące działalności gospodarczej.

W przypadku drugiej grupy podatników gromadzenie bitcoinów może być formą oszczędzania lub inwestycji bez możliwości kontroli posiadanych przez nich zasobów ze strony organów państwowych. W tym przypadku bitcoin jest traktowany jako prawo majątkowe (w obszarze gromadzenia oszczędności lub inwestycji). Transakcja zbycia bitcoinów jest przychodem z praw majątkowych, przy czym opodatkowana będzie różnica pomiędzy przychodami ze sprzedaży a kosztami ich uzyskania w danym roku podatkowym.

W obszarze opodatkowania praw majątkowych na uwagę zasługuje interpretacja indywidualna wydana przez Izbę Skarbową w Łodzi (IPTPB1/4511-583/15-4/ MD, 2015). Tamtejszy organ podatkowy uznał, że dochody z praw majątkowych sumują się łącznie z innymi dochodami i powinny być opodatkowane stawką 18 lub 32\% oraz wykazane w rocznym zeznaniu podatkowym (PIT-36). Warto dodać, że jeśli przychód powstanie z chwilą zbycia cyfrowej waluty, to w danym roku możliwe będzie odliczenie kosztów jej nabycia. W praktyce oznacza to, że jeśli w 2016 r. sprzedano zakupioną w 2015 r. kryptowalutę, to w 2015 r. podatnik 
nie ma prawa zaliczyć kosztów jej nabycia do kosztów uzyskania przychodów. Koszty te wykaże w 2016 r., pomniejszając przychód ze sprzedaży.

Osoby fizyczne prowadzące działalność gospodarczą stanowią grupę podatkową, która ze względu na formę opodatkowania może rozliczać się na zasadach ogólnych lub korzystać z uproszczonych form opodatkowania: ryczałtu od przychodów ewidencjonowanych bądź karty podatkowej. To z kolei rodzi pytanie, czy wszystkie formy opodatkowania działalności gospodarczej są jednakowo dostępne dla zainteresowanych obrotem kryptowalutami.

W świetle obecnych przepisów osoby fizyczne zajmujące się handlem kryptowalutą nie mogą korzystać $z$ opodatkowania w formie karty podatkowej. Natomiast w kwestii opodatkowania przychodu z obrotu kryptowalutą ryczałtem od przychodów ewidencjonowanych według stawki 3\% pozytywne stanowisko zajęła Izba Skarbowa w Poznaniu w dniu 29 czerwca 2016 r. (ILPB1/4511-1-261/16-6/PP). Wnioskodawca chciał pozyskiwać wirtualną walutę w sposób pierwotny, „kopiąc”, lub w drodze zakupu za pośrednictwem giełdy internetowej. W interpretacji urzędników opodatkowanie w formie ryczałtu działalności wskazanej przez zainteresowanego nie jest ograniczone art. 8 o zryczałtowanym podatku od osób fizycznych. A zatem zgodnie z art. 12 ust. 1 pkt 3 lit. b) i pkt 5 lit. b) ustawy z dnia 26 lipca 1991 r. o podatku dochodowym od osób fizycznych (Dz.U. z 1991 r. Nr 80, poz. 350; dalej: ustawa o podatku dochodowym) uprawnione jest stosowanie 3\% stawki, przy czym powyższą działalność uznano jako usługową w obszarze handlu. Stanowisko tożsame w tej sprawie przyjęły wcześniej Izby Skarbowe: w Warszawie dnia 29 października 2015 r. (IPPB1/4511-1078/15-2/EC), w Poznaniu dnia 30 października 2014 r. (ILPB1/415-746/14-4/AA) oraz w Łodzi dnia 18 lipca 2014 r. (IPTPB1/415-221/14-10/KSU).

Zagadnienia dotyczące handlu kryptowalutą są wieloaspektowe i wymagają również analizy wpływu różnic kursowych na przychody i na koszty podatkowe. Kurs kryptowaluty jest wysoce niestabilny, dlatego podatnik zadał pytanie: „czy przychody i koszty podatkowe $z$ handlu bitcoinem podlegają korekcie o różnice kursowe?”. Izba Skarbowa w Warszawie (IPPB1/4511-68/16-4/EC, 2016) uznała, że

w świetle obowiązujących w Polsce aktów prawnych bitcoin nie jest walutą uznawaną za prawny środek płatniczy i nie funkcjonuje jako instrument rynku pieniężnego, dlatego przychody i koszty podatkowe przedsiębiorstw zajmujących się handlem wirtualną walutą bitcoin nie będą podlegały korekcie o różnice kursowe.

Wyjaśniła, że art. 24c ustawy i podatku dochodowym stosuje się wobec kursu walutowego wyrażonego w walucie obcej, a bitcoin nie jest traktowany jak waluta obca. 
Kolejna kwestia w sprawie bitcoina wiąże sie z „dokumentowaniem przebiegu transakcji dla celów podatku od towarów i usług oraz podatku dochodowego". Wymóg ten był konieczny, by uznać za rzetelne rozliczenia prowadzone w formie księgi rachunkowej, podatkowej księgi przychodów i rozchodów czy też ewidencji przychodów dla podatników rozliczających się na zasadach ryczałtu od przychodów ewidencjonowanych. Anonimowość wirtualnych walut sprawia, że realizacja tego warunku jest w praktyce utrudniona. Ograniczone bowiem możliwości weryfikacji tożsamości stron dokonujących transakcji, np. w przypadku operacji transgranicznych, utrudniają bądź uniemożliwiają skorzystanie ze zwolnień podatkowych wynikających z umów międzynarodowych o zapobieganiu podwójnemu opodatkowaniu. Dokumentem potwierdzającym dokonanie transakcji gospodarczych jest zazwyczaj faktura, zawierająca nazwy podatników-sprzedawców oraz nabywców towaru/usługi wraz z ich adresami (art. 106e ust. 1 ustawy o podatku VAT). Jednakże od początku 2014 r. nastąpiła zmiana dająca możliwość wystawiania faktury uproszczonej, czyli bez obowiązku podawania powyższych danych, choć jej zastosowanie jest ograniczone do drobnych transakcji, nieprzekraczających kilkuset złotych. Dodatkowo zwolnienie z opodatkowania VAT transakcji bitcoinowych w sposób znaczący upraszcza sprawę, gdyż podatnicy (art. 43 ust. 1 ustawy z dnia 11 marca 2004 r. o podatku od towarów i usług, Dz. U. z 2021 r. poz. 685; dalej: ustawa o podatku od towarów i usług) nie są zobowiązani do fakturowania sprzedaży zwolnionej z podatku VAT. Na elementy dowodu księgowego, w tym określenie stron transakcji, wskazuje także art. 21 ustawy z dnia 29 września 1994 r. o rachunkowości (Dz. U. z 2021 r. poz. 217), przy czym ust. la pkt 1 tego artykułu daje możliwość zaniechania zamieszczania danych stron transakcji, jeśli wynika to z odrębnych przepisów (Prokurat, 2016).

Poszukując przepisów dotyczących sposobów dokumentowania transakcji, należy sięgnąć do ustawy z dnia 29 sierpnia 1997 r. - Ordynacja Podatkowa (Dz. U. z 2021 r. poz. 1540), bazy interpretacji aktów prawa podatkowego. Zgodnie z art. 180 Ordynacji za „dowód należy dopuścić wszystko, co może przyczynić się do wyjaśnienia sprawy, a nie jest sprzeczne z prawem". A zatem w świetle ustawy dokumentem transakcji bitcoinowej może być zapis w systemie informatycznym dokumentujący zawarcie transakcji lub wydruk potwierdzający zapłatę.

Na uwagę zasługuje jeszcze jeden przykład interpretacji indywidualnej, w której wnioskodawca dopytuje: „czy w chwili bezpośredniej wymiany bitcoin (BTC) na inną krytowalutę, np. na Litcoin (LTC) powstaje przychód u wnioskodawcy i jednoczesny koszt?". Według stanowiska wnioskodawcy nie dochodzi tu do zamiany wartości wirtualnej na tradycyjną. Nie można więc odnieść 
tej transakcji do waluty tradycyjnej, gdyż parytet wymiany nie jest określany w pieniądzu. Jak zatem dokonać wyceny takiej transakcji, jeśli brak ustalonej między stronami wartości w walucie, a kurs wymiany odnosi się do BTC? Strony nie dokonują między sobą żadnych dopłat w pieniądzu tradycyjnym, jeżeli w danej chwili kurs na giełdach każdej z walut nie jest ekwiwalentny, tzn. nie da się dokonać takiej wymiany, aby cena wyrażona np. w PLN/BTC odpowiadała dokładnie ilości i cenie drugiej kryptowaluty (0113-KDIPT2-3.4011.479.2017.1.RR). Organ podatkowy udzielił interpretacji, nawiązując do określonych w ustawie o podatku dochodowym (poz. 1128) źródeł przychodów (gdzie jednym z nich jest pozarolnicza forma aktywności gospodarczej). W myśl art. 11 ust. 1 ww. ustawy przychodami wynikającymi z pochodnych instrumentów finansowych są: „otrzymane/postawione do dyspozycji podatnika w roku kalendarzowym środki i wartości pieniężne oraz otrzymane wartości w naturze i inne nieodpłatne świadczenia”. Jeśli chodzi o wzajemną zamianę kryptowalut, to nie można ich traktować jako przewalutowania narodowych walut (np. euro na dolary). Zamianę w obszarze kryptowalut - jednych na drugie - powinno się uznać jako konwersję jakichkolwiek wierzytelności. W efekcie można mówić o zbyciu jednego dobra w zamian za nabycie drugiego o wartości wyrażonej w tradycyjnym pieniądzu. Jeśli w dokonywanej transakcji nie występuje tradycyjny pieniądz, po stronie podatnika powstanie przychód (art. 14 ust. 1c ustawy o podatku dochodowym), gdy nastąpi zamiana jednej cyberwaluty na drugą, a wydatek na nabycie kryptowaluty w ramach transakcji wymiany kryptowalut będzie kosztem uzyskania przychodu (art. 22 ust. 1 ustawy o podatku dochodowym) w momencie dokonania takiej transakcji. Podobnie jak w interpretacjach sprzed kilku lat organ podatkowy przypomina:

w świetle polskiego prawa kryptowalut nie można traktować na równi z prawnym środkiem płatniczym. Kryptowaluty nie są pieniądzem elektronicznym, nie mieszczą się w zakresie ustawy z dnia 19 sierpnia 2011 r. o usługach płatniczych (Dz. U. z 2017 r., poz. 2003, z późn. zm.) oraz ustawy z dnia 29 lipca 2005 r. o obrocie instrumentami finansowymi (Dz. U. z 2017 r., poz. 1768, z późn. zm.). Nie są również stosowane w rozliczeniach międzynarodowych w sensie prawnym i nie posługują się nimi żadne instytucje publiczne (0113-KDIPT2-3.4011.479.2017.1.RR).

Konkludując, można stwierdzić, że w Polsce brakuje jednoznacznej wykładni prawa podatkowego obowiązującej na terenie całego kraju, a interpretacje zapisów regulacji ustawowych są wysoce uznaniowe. Taki stan rzeczy przyczynia się do dezinformacji podatników oraz stanowi ważną barierę w rozwoju przedsię- 
biorczości. Można zaryzykować stwierdzenie, że uznaniowe podejście organów skarbowych szkodzi zarówno społeczeństwu, jak i państwu. Wymaga więc zmian. Póki to jednak nie nastąpi, należy pozytywnie oceniać wyrok TSUE, wyznaczający kierunek prawa podatkowego w zakresie traktowania rynku wirtualnych walut.

\section{Kierunki zmian w regulacjach prawnych}

W efekcie wydanego wyroku TSUE należy spodziewać się zmiany podejścia polskich organów podatkowych w obszarze opodatkowania kryptowalut podatkiem VAT. W szczególności dostosowania wymaga art. 43 ust. 1 pkt 7 ustawy o podatku od towarów i usług, który zwolnieniem z podatku VAT obejmuje usługi pośrednictwa w zakresie walut, banknotów i monet uznawanych jako prawny środek płatniczy, wyłączając z tego obszaru środki kolekcjonerskie i numizmatyczne w postaci banknotów i monet ze złota, srebra lub innego metalu (Prokurat, 2015, s. 2). Brak atrybutu prawnego środka płatniczego, stanowiący negatywną przesłankę dla zwolnienia kryptowalut z podatku VAT, w przypadku polskich organów skarbowych nie jest kwestią zasadniczą. Przed podjęciem odpowiednich decyzji legislacyjnych oraz w celu wyjaśnienia narastających wątpliwości wokół zainteresowania obrotem kryptowalutami istotne wydaje się oświadczenie ministra finansów dotyczące ogólnej interpretacji prawa podatkowego w związku z wyrokiem TSUE. Wyrok trybunału powoduje, że polskie sądy i organy podatkowe, tak jak organy państw członkowskich UE, powinny uwzględniać jego orzecznictwo w interpretacjach podatkowych dotyczących obrotu kryptowalutami.

Najnowszym uregulowaniem biznesowego obrotu wirtualnymi walutami jest piąta Dyrektywa Parlamentu Europejskiego (UE) 2018/843 z dnia 30 maja 2018 r. zmieniająca dyrektywę (UE) 2015/849 w sprawie zapobiegania wykorzystywaniu systemu finansowego do prania pieniędzy lub finansowania terroryzmu oraz zmieniająca dyrektywy 2009/138/WE i 2013/36/UE. Nowe przepisy rozszerzają dotychczasowy zakres podmiotów (instytucji kredytowych i finansowych) podlegających - zgodnie z dyrektywą - rejestracji i kontroli o giełdy i dostawców portfeli zaangażowanych w biznes kryptowalutowy. Państwom członkowskim pozostawiono czas na zaimplementowanie przepisów dyrektywy do dnia 10 stycznia 2020 r. (Dyrektywa Parlamentu Europejskiego i Rady (UE), 2018).

Przyjęcie dyrektywy wydaje się pozytywnym ruchem w kierunku ochrony użytkowników wirtualnych walut. Świadczący usługi wymiany pomiędzy cyfrowymi a fiducjarnymi walutami oraz dostawcy kryptowalutowych kont powinni 
dostarczać informacje pozwalające na identyfikację stron dokonujących transakcji. Jednakże nie rozwiąże to w pełni problemu anonimowości transakcji, ponieważ duża część użytkowników wirtualnych walut pozostanie nieujawniona, dokonując ich bez pośrednictwa dostawców (punkt 9 ww. Dyrektywy).

Obrany kierunek pozwala ustawodawcom na pewną kontrolę rynku kryptowalut, umożliwia też obserwację jego rozwoju, a także lepsze poznanie technologii i wykorzystanie jej w celu kreacji cyfrowych walut narodowych. Ma to już ma miejsce w wielu krajach ${ }^{8}$, przy czym Chiny są prawdopodobnie światowym liderem w opracowywaniu krajowej waluty cyfrowej (Kharpal, 2021). Należy jednak pamiętać, że zdecentralizowany system blockchain to zasadniczo zupełnie inny system, różniący się od scentralizowanych cyfrowych walut emitowanych i kontrolowanych przez banki centralne.

\section{Zakończenie}

Z przeprowadzonej w niniejszym artykule analizy wynika, że istnieje wiele przepisów prawa podatkowego, które wystarczy implementować po wcześniejszym dopuszczeniu wirtualnych walut do legalnego obrotu. W obliczu braku uznawalności kryptowalut organy państwowe nie są jeszcze dostosowane do ich jednoznacznego zakwalifikowania w obecnych regulacjach prawno-podatkowych. Interpretacje izb skarbowych nie zawsze są zgodne, co wywołuje niepewność wśród ich użytkowników, a zainteresowanie kryptowalutami rośnie. Przekłada się to na liczbę indywidualnych zapytań o dalsze rozstrzygnięcia podatkowe i kwestii spornych. Na dzień 3 lipca 2016 r. na stronie Ministerstwa Finansów zamieszczono 39 indywidualnych i ogólnych interpretacji podatkowych, a na dzień 15 kwietnia 2021 r. było ich już łącznie 224, co potwierdza wagę problematyki wirtualnych walut. Można stwierdzić, że w ciągu ostatnich 5 lat niewiele zmieniło się w interpretacjach polskich organów podatkowych w kwestii podejścia do wirualnych walut. Ograniczenie lub zakazanie obrotu bitcoinem nie jest możliwe ze względu na rodzaj podstawy informatycznej.

Podobnie jak w przypadku innych przełomowych technologii ustawodawcy starają się nadążać za tempem rozwoju rynku wirtualnych walut. Działania państw, które próbują jeszcze ograniczać użytkowanie bitcoina, mają charakter tymczasowy. Dodatkowym argumentem za urelegulowaniem kwestii wirtualnych

8 Wiele krajów wprowadza obecnie projekty cyfrowych walut narodowych, m.in. USA, Wielka Brytania, UE, Chiny. Przy czym Chiny testują digital juan od 2014 r. 
walut jest narastający problem niewydolnego, globalnego systemu finansowego, którego konieczność zmian dyskutuje się już od wielu lat. W przypadku wirtualnej waluty, a zwłaszcza bitcoina, mamy do czynienia ze środkiem, który może przynieść wieloaspektowe zaspokojenie potrzeb społecznych w sferze finansowej. W Europie powstają już pierwsze przepisy i regulacje. Należy jednak pamiętać, by rynki wirtualnych walut były dostępne zarówno pod względem regulacyjnym, jak i finansowym, a nowe przepisy nie tworzyły zbyt wysokich barier wejścia.

\section{Bibliografia}

\section{Akty prawne}

Dyrektywa Parlamentu Europejskiego i Rady (UE) 2018/843 z dnia 30 maja 2018 r. zmieniająca dyrektywę (UE) 2015/849 w sprawie zapobiegania wykorzystywaniu systemu finansowego do prania pieniędzy lub finansowania terroryzmu oraz zmieniająca dyrektywy 2009/138/WE i 2013/36/UE (Tekst mający znaczenie dla EOG), Dz. Urz. UE L 156/43 z 19.6.2018. Pobrano z https://eur-lex.europa.eu/ legal-content/EN/TXT/?uri=CELEX\%3A32018L0843 (19.05.2021).

Ustawa z dnia 20 listopada 1998 r. o zryczałtowanym podatku dochodowym od niektórych przychodów osiąganych przez osoby fizyczne, Dz. U. z 2015 r. poz. 1893 z późn. zm. Ustawa z dnia 11 marca 2004 r. o podatku od towarów i usług Dz. U. z 2016 r. poz. 710. Ustawa z dnia 19 sierpnia 2011 r. o usługach płatniczych, Dz. U. z 2020 r. poz. 794.

\section{Interpretacje izb skarbowych}

Dyrektor Izby Skarbowej w Katowicach, Interpretacja indywidualna z dnia 21 czerwca 2013 r., sygn. IBPP2/443-258/13/ICz, nr 354133/I. Pobrano z https://interpretacje-podatkowe.org/waluta/ibpp2-443-258-13-icz (28.06.2016).

Dyrektor Izby Skarbowej w Łodzi, Interpretacja indywidualna z dnia 7 kwietnia 2014 r., sygn. IPTPP2/443-52/14-6/IR, nr 387455/I. Pobrano z http://sip.mf.gov.pl (20.06.2016).

Dyrektor Izby Skarbowej w Łodzi, Interpretacja indywidualna z dnia 18 lipca 2014 r., sygn. IPTPB1/415-221/14-10/KSU, nr 400009/I. Pobrano z http://sip.mf.gov.pl (28.06.2016).

Dyrektor Izby Skarbowej w Łodzi, Interpretacja indywidualna z dnia 21 grudnia 2015 r., sygn. IPTPB1/4511-583/15-4/MD, nr 455434/I. Pobrano z http://sip.mf.gov.pl (20.06.2016).

Dyrektor Izby Skarbowej w Poznaniu, Interpretacja indywidualna z dnia 30 października 2014 r., sygn. ILPB1/415-746/14-4/AA, nr 417037/I. Pobrano z http://sip.mf.gov.pl (28.06.2016). 
Dyrektor Izby Skarbowej w Poznaniu, Interpretacja indywidualna z dnia 29 czerwca 2016 r., sygn. ILPB1/4511-1-261/16-6/PP, nr 478637/I. Pobrano z http://sip.mf.gov.pl (28.06.2020).

Dyrektor Izby Skarbowej w Warszawie, Interpretacja indywidualne z dnia 24 czerwca 2014 r., sygn. IPPP2/443-334/14-2/BH, nr 398072/I. Pobrano z https://interpretacje-podatkowe.org/dlug/ippp2-443-334-14-2-bh (19.05.2021).

Dyrektor Izby Skarbowej w Warszawie, Interpretacja indywidualna z dnia 17 lipca 2014 r., sygn. IPPB1/415-433/14-2/JB, nr 396832/I. Pobrano z http://sip.mf.gov. $\mathrm{pl}(28.06 .2016)$.

Dyrektor Izby Skarbowej w Warszawie, Interpretacja indywidualna z dnia 24 czerwca 2015 r., sygn. IPPP2/4512-280/15-2/BH, nr 433154/I. Pobrano z http://sip.mf.gov.pl (28.06.2020).

Dyrektor Izby Skarbowej w Warszawie, Interpretacja indywidualna z dnia 21 października 2015 r., sygn. IPPP3/4512-626/15-2/RD, nr 445735/I. Pobrano z http://sip. mf.gov.pl (28.06.2016).

Dyrektor Izby Skarbowej w Warszawie, Interpretacja indywidualna z dnia 29 października 2015 r., sygn. IPPB1/4511-1078/15-2/EC, nr 446127/I. Pobrano z http://sip. mf.gov.pl (28.06.2016).

Dyrektor Izby Skarbowej w Warszawie, Interpretacja indywidualna z dnia 15 lutego $2016 \mathrm{r}$., sygn. IPPP3/4512-1005/15-2/RD, nr 462249/I. Pobrano z http://sip.mf.gov.pl (28.06.2016).

Dyrektor Izby Skarbowej w Warszawie, Interpretacja indywidualna z dnia 20 kwietnia 2016 r., sygn. IPPB1/4511-68/16-4/EC, nr 472280/I. Pobrano z http://sip.mf.gov.pl (28.06.2017).

Dyrektor Krajowej Informacji Skarbowej, Interpretacja indywidualna z dnia 24 listopada 2017 r. (data wpływu 4 grudnia 2017 r.), uzupełnionym pismem z dnia 29 stycznia 2018 r. (data wpływu 29 stycznia 2018 r.) oraz pismem z dnia 30 stycznia $2018 \mathrm{r}$. (data wpływu 30 stycznia 2018 r.), sygn. 0113-KDIPT2-3.4011.479.2017.1.RR, nr 525837/I. Pobrano z http://sip.mf.gov.pl (15.04.2021).

\section{Literatura}

Arnfield, R. (2015). Regulation of Virtual Currencies. A Global Overview. Pobrano z http:// www.nfcidea.pl/wpcontent/uploads/2015/02/Regulation-if-VirtualCurrancies-by-Jumio.pdf (20.05.2021).

BaFin. (2011). Hinweise zu Finanzinstrumenten nach $\$ 1$ Abs. 11 Sätze 1 bis 5 KWG (Aktien, Vermögensanlagen, Schuldtitel, sonstige Rechte, Anteile an Investmentvermögen, Geldmarktinstrumente, Devisen, Rechnungseinheiten, Emissionszertifikate und Kryptowerte). Merkblatt Finanzinstrumente. Pobrano z https://www.bafin.de/ 
SharedDocs/Veroeffentlichungen/DE/Merkblatt/mb_111220_finanzinstrumente. html (15.06.2021).

BaFin. (2016). Virtuelle Währungen/Virtual Currency (VC). Pobrano z https://www. bafin.de/DE/Aufsicht/FinTech/VirtualCurrency/virtual_currency_node.html (15.06.2021).

Brito, J., Castillo, A. (2016). Bitcoin. A Primer for Policymakers. Arlington: George Mason University.

EBC Eurosystem (2012, październik). Virtual Currency Schemes. Pobrano z https://www. ecb.europa.eu/pub/pdf/other/virtualcurrencyschemes201210en.pdf

EBC Eurosystem (2015, luty). Virtual Currency Schemes - a further analysis. Pobrano $\mathrm{z}$ https://www.ebc.europa.eu/pub/pdf/other/virtualcurrencyschemesen.pdf

El Salvador divided over legal tender law, BBC News, 3.09.2021.

Hill, J. (2013, 6 grudnia). Bitcoin in China. The fall-out from Chinese government banning real world use. Forbes. Pobrano z http://www.forbes.com/sites/kashmirhill/2013/12/06/bitcoin-in-china-the-fall-out-from-chinese-government-banning-real-world-use/

HM Treasury (2015, marzec). Digital currencies: response to the call for information. Pobrano z https://assets.publishing.service.gov.uk/government/uploads/system/ uploads/attachment_data/file/414040/digital_currencies_response_to_call_for_ information_final_changes.pdf

Hurtado, P. (2017, 28 stycznia). Bitcoin Group Says Shrem Quit Board After Arrest. Bloomberg Businessweek.

Kharpal, A., CNBC. (2021, 4 marca). China has given away millions in its digital yuan trials. This is how it works. Pobrano $\mathrm{z}$ https://www.cnbc.com/2021/03/05/chinas-digital-yuan-what-is-it-and-how-does-it-work.html (19.05.2021).

Kiszka, J. (2016, 14 marca). Skutki wymiany walut tradycyjnych na jednostki wirtualnej waluty „Bitcoin” w świetle wyroku TSUE w sprawie C-264/14 i interpretacji indywidualnych. Serwis Doradztwa Podatkowego nr 000343. Pobrano z http://www. isp-modzelewski.pl/pl/component/content/article?id=783\&start=3 (28.06.2016). Ledger, D.L. (2014, 28 stycznia). Bitcoin pioneer facing federal charges quits foundation. USA Today. Pobrano z https://eu.usatoday.com/story/tech/2014/01/28/shrem-resigns-from-bitcoin-foundation/4961903/ (10.09.2021).

Lam, P.N., Lee, D.K.C. (2015). A Light Touch of Regulation for Virtual Currencies. W: D. Lee (red.), Handbook of Digital Currency. Bitcoin, Innovation, Financial Instruments, and Big Data (s. 309-326). Amsterdam: Elsevier.

Marszałek, P. (2019). Kryptowaluty - pojęcie, cechy, kontrowersje. Studia BAS, 1(57), 105-125. 
Middlebrook, S.T., Hughes, S.J. (2014). Regulating Cryptocurrencies in the United States: Current Issues and Future Directions. William Mitchell Law Review, 40(2), 813-848.

Münzer, J. (2014). Bitcoins. Aufsichtliche Bewertung und Risiken für Nutzer, BaFin Journal, 2014.

Palczewski, S. (2020, 20 marca). Kryptowaluty nielegalne $w$ Rosji? Twarde stanowisko Banku Centralnego. CyberDefence24. Pobrano z https://www.cyberdefence24. pl/kryptowaluty-nielegalne-w-rosji-twarde-stanowisko-rosyjskiego-banku-centralnego (19.05.2020).

Prokurat, J. (2015, listopad). Bitcoin zwolniony z VAT w całej Unii Europejskiej. Wardyński i Wspólnicy. Pobrano z http://www.wardynski.com.pl/biuletyn_nowych_technologii/2015-11/B08_PL_Bitcoin_zwolniony_z_VAT.pdf (28.06.2016).

Prokurat, J. (2015). Dokumentowanie transakcji z użyciem wirtualnej waluty. Pobrano z http://www.podatki.abc.com.pl/czytaj/-/artykul/dokumentowanie-transakcji-z-uzyciem-wirtualnej-waluty (20.07.2016).

Przyłuska-Schmitt, J. (2016). Bitcoin - intrygująca innowacja. Bank i Kredyt, 47(2), 137-152. Ramasastry, A. (2014, 25 lutego). Bitcoin: If You Can't Ban It, Should You Regulate It? The Merits of Legalization, Verdict Justia, 25 February 2014. Pobrano $\mathrm{z}$ https://verdict. justia.com/2014/02/25/bitcoin-cant-ban-regulate (20.05.2021).

Rusinowski, J. (2015). Ministerstwo Finansów o Bitcoin. Pobrano z http://www.coinformacje.pl/2015/10/15/ministerstwo-finansow-o-Bitcoin/ (28.06.2016).

Sandner, P., Blassl, J. (2020, 7 stycznia). Blockchain steht nun unter BaFin Aufsicht, Neue Regulierung digitaler Vermögenswerte. Legal Tribune Online. Pobrano z https:// www.lto.de/recht/hintergruende/h/blockchain-bitcoin-regulierung-bafin-aufsicht-digitale-vermoegenswerte-erlaubnis/ (18.05.2021).

Schmid, F. (2019). Virtuelle Währungen - Das Zahlungsmittel der Zukunft? Vergleich zwischen der rechtlichen Regulierung ausgewählter Staaten (t. 19). Ulm: Ulm Universität.

Stevenson, A. (red.). (2010). Oxford Dictionary of English (3 $3^{\text {rd }}$ ed). Pobrano z www. oxfordreference.com.

Tu, K.V., Meredith, M.W. (2015). Rethinking virtual currency regulation in the bitcoin age. Washington Law Review, 90(1), 271-347.

Wasilewska, A. (2015, 7 grudnia). Polski fiskus musi zmienić podejście do bitcoinów. Dziennik Gazeta Prawna. Pobrano z http://www.itadp.pl/dziennik-gazeta-prawna-7/ (28.06.2016).

Wile, R. (2014, 27 stycznia). CEO of Bitcoin Exchange Arrested. Business Insider. Pobrano z https://www.businessinsider.com/report-ceo-of-major-bitcoin-exchange-arrested-2014-1?IR=T (20.06.2016). 


\section{Streszczenie}

Błyskawiczny rozwój systemów wirtualnych walut o zasięgu globalnym powoduje, że problematyka ich prawnego uregulowania staje się koniecznością. Systemu bitcoin i jemu podobnych - nie da się zamknąć ani zabronić, dlatego coraz więcej krajów koncentruje się na „wymuszonej” akceptacji traktowania tego typu walut jako środka płatności w transakcjach handlowych. Jednak ich podejście do problematyki alternatywnej waluty jest zróżnicowane. W zależności od stopnia zaangażowania poszczególnych państw dostosowanie przepisów do potrzeb współczesnego systemu walutowego wydaje się wielkim wyzwaniem. W artykule przedstawiono podejście wybranych krajów do rynku wirtualnych walut na przykładzie bitcoina oraz potrzebę wprowadzenia regulacji prawno-podatkowych niezbędnych do legalnego ich użytkowania. W dalszej części skoncentrowano się na interpretacjach podatkowych polskich izb skarbowych. Liczba składanych zapytań interpretacyjnych wskazuje, że problem ich legalnego użytkowania musi być jednoznacznie rozwiązany.

SŁoWA KLUCZOWE: bitcoin, wirtualne waluty, regulacje podatkowe.

\section{Summary}

The rapid development of global virtual currencies means that the issue of their legal regulation becomes a necessity. The Bitcoin system cannot be shut down or prohibited, therefore more and more countries focus on the "forced" acceptance of this type of payment in commercial transactions. However, their approach to the issue of an alternative currency varies. Depending on the degree of involvement of individual countries, adapting regulations to the modern monetary system looks like a major challenge. The aim of the article is to present the attitude of selected countries towards virtual currencies, especially bitcoin and related legal and tax regulations. The next part of the article focuses on interpretations of Polish taxes. The number of interpretative querries submitted shows that the problem of the legal use of such currencies must be resolved.

KEYWORDs: bitcoin, virtual currencies, legal use, tax regulation.

\section{Nota o autorze}

Judyta Przyłuska-Schmitt - dr, Katedra Globalnej Ekonomii Politycznej, Instytut Ekonomii i Finansów, Wydział Nauk Społecznych, Katolicki Uniwersytet Lubelski Jana Pawła II; główne obszary działalności naukowej w dyscyplinie ekonomii i finansów, gospodarka ubezpieczeniowa oraz współczesne formy pieniądza; e-mail: judyta.przyluska-schmitt@kul.pl; ORCID: 0000-0002-5320-2410. 
